\title{
СЕМАНТИКА ТА СТИЛІСТИЧНІ ФУНКЦЇ̈ ПРИКМЕТНИКІВ ЖОВТОГО КОЛЬОРУ В ЛАТИНСЬКІЙ МОВІ (на матеріалі творів августівського періоду)
}

У статті проведено комплексне дослідження семантичних та стилістичних функцій прикметників жовтого кольору в латинській мові на матеріалі поетичних творів Квінта Горація Флакка, Публія Овідія Назона й Публія Вергілія Марона. Виконано аналіз особливостей художньої реалізації прикметників жовтого кольору, семантичної структури основних кольоропозначень. Виокремлено ядро, навколоядерну, периферійну та дифузну зони. Лексикосемантичне поле прикметників жовтого кольору кількісно багате й семантично розгалужене, оскільки включає лексичні одиниці, які позначають різноманітні відтінки жовтого. Дослідження продемонструвало, що лексема flavus є семантичним центром лексико-семантичного поля. Навколоядерну зону становлять auratus, aureus, croceus, flavens, inauratus, luteus, де основною диференційною ознакою є насиченість кольору. Лексичні одиниці cereus, fulvus, gilvus, luridus, murreus, pallens, ravus, у значенні яких жовтий колір утрачає яскравість, унаслідок чого, рівновага вираження колірної ознаки зміщується в бік темного або світлого тону, становить периферію поля. У дифузній зоні виділяємо flammifer, igneus, igniferus. Відзначено дві основні функції словотворення - номінативну та експресивно-стилістичну. Розкрито значення прикметників жовтого кольору і їхні індивідуально-авторські трансформації. Колірні означення дають змогу простежити формування й розвиток багатозначності слів. Семантика жовтого кольору - рух від конкретного порівняння до колірного узагальнення. Особливо виразними функціонально-стилістичними засобами виявилися полісемія, метафора, епітет. За допомогою цих тропів створюються яскраві художні емоційно-експресивні образи, які привертають увагу читача i, зазвичай, виражають позитивні або негативні емоції. Семантична завантаженість концепту жовтого кольору відображає не лише почуття й думки поетів, а й соціальні явища в житті античного суспільства. Проте на вибір лексеми, передусім, впливає подих античної доби та відчуття кольору авторами.

Ключові слова: лексико-семантичне поле, прикметники кольору, деривація, лексема, функціональностилістичні особливості, метафора, епітет.

Актуальність дослідження. У ході дослідження якісно нового рівня семантики прикметників кольору в латинській мові класичного періоду, як ніколи, актуальною постає проблема визначення лексико-семантичного поля певного кольору, що є складовою частиною загального лексико-семантичного поля прикметників кольору. Основну увагу важливо приділити критеріям формування лексико-семантичного поля.

У роботі досліджено семантику прикметників жовтого кольору. Мета нашої статті визначення семантичних i стилістичних особливостей прикметників жовтого кольору на матеріалі поетичних творів Горація, Овідія й Вергілія. Об'єктом дослідження є прикметники, що позначають жовтий колір у творах античних поетів. Предмет вивчення - семантичні особливості та стилістичні функції прикметників, що утворюють лексико-семантичне поле жовтого кольору. Для дослідження використано матеріал оригінальних пам’ятників [9].

Методи та методики дослідження. Найяскравіше колористична культура виявилася за доби античності. Про це стверджує Л. В. Бичкова в праці «Колористична культура античного світу». Авторка зосередила увагу на процесах формування й розвитку колірної культури 3 урахуванням «динаміки політичних та ідеологічних настанов, що панують у суспільстві» [2]. Досліджуючи проблеми функціонування прикметникових лексичних синонімів у старогрецькій мові, О. І. Малиновська зробила вагомий внесок у теорію семантичних полів стародавніх мов. Дослідниця з'ясувала специфіку формування синонімічного ряду окремих прикметників, проаналізувала їхню семантичну структуру й особливості функціонування [11]. Питання щодо визначення меж лексико-семантичного поля прикметників кольору в мові Гомера розглянуто в праці Н. К. Малінаускене [10]. Жовтий колір поширений у природі, він асоціюється, передусім, зі світлом, сонячним сяйвом. Цей колір викликає, як зазначає I. В. Гете [7], бадьорий настрій, як i енергійний жовтогарячий. Співвіднесеність кольору з його еталонним носієм, згідно $з$ теорією А. Вежбицької [5], передбачає не абстрактність кольору, а його зв'язок із природними об'єктами, яким властивий той чи інший колір. На думку дослідниці, еталоном жовтого кольору $\epsilon$ сонце. Здійснюючи порівняльний опис кольоропозначень у стародавніх та індоєвропейських 
мовах, Ю. В. Норманська [12, с. 54] вказує на низку труднощів, які виникають, коли дослідження проводиться на основі мертвих мов. Зокрема, треба враховувати можливість сполучуваності лексичних одиниць, частоту їх уживання та наявність конотацій. Е. В. Рахіліна зазначає, що «для мертвої мови труднощі полягають ще й у тому, що не можна перевірити, чому певне кольоропозначення не трапилося в тому чи іншому словосполученні» [14, с. 33].

Результати та дискусії. Психологічне сприйняття жовтого кольору двопланове. В античному суспільстві жовтий колір асоціюється з кольором сонця, веселості. Одночасно йому властиві негативні характеристики внаслідок асоціації з хворобливим відтінком шкіри - він постає символом смерті та хвороби. Як наслідок, прикметники, що позначають жовтий колір, перебувають у семантичній опозиції. Дослідження психолінгвістів [4, с. 22] указують, що в представників різних національностей виникають різні асоціації під час сприймання одного й того самого кольору, що дає підставу говорити про кольоропозначення як своєрідні «концепти світобачення», «словеснообразні лейтмотиви».

Лексико-семантичне поле прикметників жовтого кольору кількісно багате й семантично розгалужене, оскільки включає лексичні одиниці, які позначають різноманітні відтінки жовтого. Ядерним компонентом аналізованого лексико-семантичного поля $є$ прикметник flavus. Хоча А. I. Солопов зазначає, що «поняття 'помаранчевий' і 'жовтий' кілька разів упродовж античного періоду змінювали кольоропозначення (luteus, flavus, galbinus), що вказує на відносну нестійкість, а можливо й вторинність цих понять для латинської системи кольоропозначень» [15, c.69]. Навколоядерну зону становлять auratus, aureus, croceus, flavens, inauratus,luteus, диференційною ознакою яких є насиченість кольору. Лексичні одиниці cereus, fulvus, gilvus, luridus, murreus, pallens, ravus, у значенні яких жовтий колір утрачає яскравість, тому рівновага вираження колірної ознаки зміщується у бік темного або світлого тону, утворюють периферію поля. Дифузну зону становлять flammifer, igneus, igniferus. У значенні цих лексем є значення 'колір вогню', що пов'язане 3 прототипом природної реалії. Перелік компонентів лексикосемантичного поля вказує на їх різноплановість щодо формального вираження й семантичного наповнення. Об'єкти - носії жовтого кольору та його відтінків у поетичній мові позначені широкою різноплановістю. Аналіз досліджуваного лексико-семантичного поля засвідчив, що конституенти поля сполучаються з іменниками тематичних груп «природні об’єкти», «людина, частини тіла», «предмети», «тварини».

Прикметник flavus має значення жовтий, золотисто-жовтий, вогняного кольору, рум'яний. У поезії Горація аналізовану лексему зафіксовано сім разів, в Овідія вона функціонує найактивніше - 34, у Вергілія - 12 разів. Серед низки слів на позначення жовтого кольору В. Г. Гак видокремлюєте лексему flavus як таку, що має значення яскраво-жовтого кольору й використовується в піднесеному стилі. Ця лексема, на думку науковця, $є$ «абстрактним, не зв'язаним із конкретними предметами значенням» [2, с. 144]. Прикметник flavus є нейтральним багатозначним словом. Його понятійний зміст має низку значень, які перетинаються. Словник Й. Дворецького [8, с. 431] подає такі значення: 1) вогняного кольору, золотисто-жовтий, золотистий; 2) жовтий, мутний; 3) рум'яний. Парадигматично та синтагматично зумовленим значенням є'жовтий'. Саме таке значення реалізовує аналізована лексема, сполучаючись із широким колом іменників, які позначають предмети і явища навколишнього світу. Виділяємо іменники таких тематичних груп, як «люди», «міфічні істоти», «водні об'єкти», «предмети побуту», що $\epsilon$ контекстними партнерами аналізованої лексеми. Прикметник $\epsilon$ епітетом іменників, які позначають богів і міфічних істот. Значення 'жовтий' указує на світлий колір волосся, який може змінювати відтінок від світло-жовтого, наближеного до білого, і аж до насиченого жовтого, що нагадує колір золота: «flavus, prorae tutela, Melanthus (Ov. Met. III 617) русявий Мелант, вахтовий на носі судна»; «doluit successu flava virago et rupit pictas, caelestia crimina, vestes (Ov. Met. VI 130) - обурилася успіхом (Арахни) русява діва і порвала вишиту тканину - образ пороків небесних». Лексема flavus є постійним епітетом іменника Minerva, ae $\mathrm{f}$ (Мінерва). Вона реалізує значення «русява», «жовтокоса» і містить диференційну сему «світложовтий колір волосся»: «adspicit hunc oculis isdem, quibus abdita nuper viderat Aglauros flavae secreta Minervae proque ministerio magni sibi ponderis aurum postulat (Ov. Met. II 749) - на нього Аглавра дивиться такими ж очима, якими недавно бачила приховані таємниці русявої Мінерви, $\mathrm{i}$ 
за цю послугу вимагає для себе чимало золота». Пряме номінативне значення має аналізований прикметник при сполученні з іменником Tiberis, is m (Тібр). В основному значенні «жовтий» міститься потенційна сема «каламутний», яка спричиняє появу конотації непрозорості: «сur timet flavum Tiberim tangere? (Hor. C. I 8, 8) - чому він (Сибаріс) боїться жовтого Тибру?». Як зазначає I. В. Гете, жовтий колір - «дуже чутливий і справляє неприємне враження, якщо він забруднений або до певної міри зсунутий у бік холодних тонів» [6, с. 324]. У сполученні з іменником mel, mellis $n$ (мед) лексема flavus набуває значення «прозоро-жовтий»: «flumina iam lactis, iam flumina nectaris ibant, flavaque de viridi stillabant ilice mella (Ov. Met. I 112) - то ріки текли молоком, то нектаром, i із зеленого дуба струменіли каплями жовті меди». Сполучаючись з іменником, який позначає назву речовини, прикметник має домінантною диференційну сему «колір речовини». Тобто семантика аналізованої лексеми залежить від семантики означуваного слова й диференційно ним умотивована.

Навколоядерна група лексем (auratus, aureus, inauratus), яка містить диференційну сему «колір золота», належить до традиційної поетично маркованої лексики. Як слушно зауважує Т. Панько, у художньому контексті «слово “золотий” виявляє таку багатоплановість, у якій тісно переплітаються загальномовні і власне поетичні смислові відтінки» [13, с. 22]. Семантикостилістичне навантаження аналізованих прикметників у поетичному мовленні визначається безпосереднім їх зв’язком з ознакою коштовного металу, яка символізує багатство та красу. Лексеми мають здатність сполучатися 3 іменниками різноманітні семантики, вільно їх характеризувати способом образного перенесення й метафоричного осмислення. На семантичному рівні в значенні 'золотий' виділяємо сему «величавий», «божественний», «славний»: «quanto splendidior quam cetera sidera fulget Lucifer et quanto quam Lucifer aurea Phoebe, tanto virginibus praestantior omnibus Herse ibat (Ov. Met. II 723) - як серед решти зірок виділяється Зірниця, і як меркне Зірниця поряд із золотою Фебою, так найвродливіша з усіх дівчат виступала вперед Герса». Означення золотий уживається з назвами предметних реалій: «зброя», «рослини», «будівлі», «предмети», «небесні об'єкти». Аналізовані лексеми і набувають прямого значення, i вживаються як метафори. Вони сприймаються через відношення до металу й водночас уживаються 3 якісним значенням. Поряд із потенційною семою «виготовлений із золота» виділяється диференційна сема «кольору золота», яка частково відступає на другий план. Предмети, виготовлені із чистого золота, своїм означенням указують не лише на колір, а й на цінність. Тому в аналізованих лексем виокремлюємо поряд з архісемою кольору потенційну сему «цінний»: «ornabant aurata monilia collum (Ov. Met. V 52) - шию прикрашало золоте намисто».

Метафоричний образ золотої гілки зумовлений виникненням нетрадиційного емотивного значення. 3'являється двозначність семантики: зеленому кольору протиставлено колір золота, неживого матеріалу: «non alta fronde virentem ilice detraxit virgam: virga aurea facta est (Ov. Met. XI 109) - відламав із невисокого дуба гілку зелену, й гілка золотою стала. Загальний зміст метафори надає лексемі позитивного емотивно-оцінного значення.

У дистрибуції з іменниками, які позначають споруди, лексеми aureus, auratus, inauratus не втрачають семи кольору, а актуалізують потенційну сему «досконалий», «прикрашений золотом»: «hinc ad Tarpeiam sedem et Capitolia ducit, aurea nunc, olim silvestribus horrida dumis (Verg. Aen. VIII 348) - звідси веде він їх до Тарпеї і до Капітолію, що тепер золотий, а колись був укритий дикими кущами терену». Оцінка закладається не в сему номінації, а експлікується в контекстному оточенні.

«Золотий вік» - вислів, що його вперше вжив старогрецький поет Гесіод (VIII-VII ст. до н. е.) у поемі «Роботи і дні» [9]. У переносному значенні - щаслива пора; епоха розквіту золотий вік відображено в «Метаморфозах» Овідія: «aurea prima sata est aetas, quae vindice nullo sponte sua, sine lege fidem rectumque colebat (Ov. Met. I 89) - вік золотий був уперше посіяний, який без жодного примусу, із власної волі, без законів шанував вірність і правду». У синтагмі aetas aurea колірна сема аналізованої лексеми поступається місцем потенційній семі 'ідеальний'. Метафорично актуалізується переносне значення 'щасливий', 'безтурботний'.

Значення прикметника flavens (жовтуватий) характеризується зменшенням інтенсивності вияву кольору: «terque quaterque тапи pectus percussa decorum, flaventesque abscissa comas (Verg. 
Aen. IV 590) - тричі й чотири рази руками ударивши прекрасні груди і розірвавши жовтувате волосся».

Лексема croceus (яскраво-жовтий, шафрановий) реалізує пряме номінативне значення. Синтагматичними партнерами аналізованої лексеми виступають іменники тематичних груп «рослини», «одяг», «частини тіла». Позитивно конотований прикметник уживається переважно для епітетної характеристики забарвлення квітки.

Прикметник luteus має значення шафрановий, золотисто-жовтий. Аналіз лексеми засвідчив, що вона виступає постійним епітетом богині Аврори. У такому словосполученні виявляється позитивна оцінність аналізованої лексичної одиниці: «vertice de summo semper florentis Hymetti lutea mane videt pulsis Aurora tenebris invitumque rapit (Ov. Met. VII 703) - i3 вершини завжди квітучого Гімета побачила мене вранці золотиста Аврора i, розвіявши темряву, проти волі повела мене із собою».

Одиничний випадок уживання лексичної одиниці gilvus (світло-жовтий, буланий), зафіксований у Вергілія, свідчить про відсутність активного функціонування цієї лексеми, що зумовлено певними як внутрішньомовними, так і позамовними факторами: «honesti spadices glaucique, color deterrimus albis et gilvo (Verg. Georg. III 83) - підхожі (коні) каштанової чи ciрої масті, найнепридатніший колір - білий і світло-жовтий». Стилістично прикметник має негативно-емотивне забарвлення.

Прикметник luridus (блідо-жовтий) на семантичному рівні втрачає сему 'яскравість', і такі фактори відсувають лексему в периферійну зону лексико-семантичного поля прикметників жовтого кольору. Так, прикметник сполучається з іменниками тематичної групи «людина, частини тіла» й має різко негативне емотивне значення. Потенційна сема «гидкий», «хворобливий» доповнює архісему 'колір' та диференційну сему «блідий»: «reliquit ossa pelle amicta lurida (Hor. Еp. 17, 22) - залишилися кістки, обтягнуті блідо-жовтою шкірою»; «et refugit te, quia luridi dentes te turparunt (Hor. Carm. IV 13, 10) - і уникає він тебе, бо тебе споганили блідо-жовті зуби». Аналізована лексема виступає епітетом бога царства тіней: «iniecta monstris Terra dolet suis maeretque partus fulmine luridum missos ad Orcum (Hor. Carm. III 4, 75) - Земля страждає, чудовиська свої сховавши, і тужить, що блискавка дітей скинула до блідо-жовтого Орка».

Семантика прикметника fulvus розширяється внаслідок спектра сполучуваності 3 іменниками різних класів. Цей прикметник залежно від семантичної категорії сполучуваного 3 ним слова реалізує різні відтінки значення. Прикметник fulvus розміщується в колірному спектрі на межі жовтого й червоного тонів, тому справедливим буде віднесення його до периферійної зони лексико-семантичного поля прикметників червоного кольору. Прикметник fulvus набуває значення 'рудий', коли позначає масть тварини. На семантичному рівні поряд 3 архісемою 'колір' виділяємо диференційну сему 'забарвлення шерсті', яка може вказувати на відтінок насиченості кольору: «fulvos leones (Ov. Met. I 304) - рудих левів»; «fulvum lupum (Ov. Met. XI 771) - рудого вовка».

Прикметник pallens (блідо-жовтий), указуючи на неповноту вияву ознаки, є означенням кольору шкіри. Семантична диференціація в такому випадку залежить від психофізичного та емоційного стану людини. Тоді лексична одиниця вказує на різні прояви лицевої експресії чи то страху, чи то хворобливості, чи інших емоційних факторів. У співвідношенні емоцій і кольорів П. В. Янишин убачає візуалізацію емоційного досвіду. Зовнішній світ людина суб'єктивно переживає емоціями, які відображуються у формі кольорів, а у формі колориту їй властиво бачити емоції [16, с. 35]. Унаслідок конкретності й раціональності блідо-жовтий колір здатний акумулювати у своїй внутрішній формі великий обсяг емоційної інформації: «illam inter caedes pallentem mortem futura fecerat Ignipotens (Verg. Aen. VIII 709) - бог вогняний зобразив іiі серед битви, блідою від передчуття смерті». У семантичній структурі лексеми домінує потенційна сема 'мертвий', яка створює сильний ефект експресії поетичних рядків.

Зафіксовано одиничне вживання лексичної одиниці ravus (сіро-жовтий) у поезії Овідія: «si straba, sit Veneri similis: si rava, Minervae (Ov. Ars amat. II 659) - якщо (дівчина) косоока, хай буде подібна до Венери, якщо світлоруса - до Мінерви». У структурі лексичного значення виділяємо архісему 'колір', диференційну сему 'колір волосся', потенційну сему 'естетично привабливий'. 
До складу дифузної зони лексико-семантичного поля жовтого кольору можна зараховувати прикметники-синоніми, пов'язані з вогнем і процесами, що його супроводжують: flammifer, igneus, igniferus (вогняний). Тобто можна стверджувати, що прикметник flammifer утворений від іменника flamma, ae f (полум'я), а igneus й igniferus - від іменника ignis, is m (вогонь). Вогонь святий, чистий, а отже, очищувальний, тому здавна за його допомогою чинили Суд Божий. Аналізовані лексеми належать до групи слів із низькою частотою вживання, стилістично обмеженою сферою функціонування та вузькою синтагматичною сполучуваністю: «interea volucres Pyrois et Eous et Aethon, Solis equi, quartusque Phlegon hinnitibus auras flammiferis inplent pedibusque repagula pulsant (Ov. Met. II 155) - крилаті сонячні коні Трой, Еой, Етон і четвертий Флегон вогняним іржанням наповнюють повітря і б’ють копитами засув».

Висновки. Отже, лексика на позначення жовтого кольору в латинській мові визначається своєю національно-культурною забарвленістю. У проведеному дослідженні проаналізовані семантичні особливості та стилістичні функції прикметників лексико-семантичного поля жовтого кольору. Перелік компонентів лексико-семантичного поля вказує на їх різноплановість щодо формального вираження й семантичного наповнення. Особливо виразними функціонально-стилістичними засобами виявилися полісемія, метафора, епітет. За допомогою цих тропів створюються яскраві художні емоційно-експресивні образи, які привертають увагу читача. У світлі сучасних віянь у сфері взаємодії лінгвокогнітології та культурології можемо стверджувати про розширення меж змісту аналізу мовних явищ, що зумовлює ефективність семантичних досліджень. Це відкриває перспективи дослідження лексичних одиниць із позиції лінгвокультурології.

\section{References}

1. Hesiod. "Opera et Dies". URL: http://ae-lib.org.ua/texts/hesiod_opera_et_dies_ua.htm

2. Bychkova, Lyubov. 2003. Kolorystychna kartyna antychnoho svitu. Kyiv.

3. Borodyna, Melytyna. 1979. K typologii i metodyke istoriko-semanticheskikh issledovaniy. Leningrad: Nauka.

4. Vasilevich, Anton. 1987. Issledovaniye leksiki v psykholingvisticheskom eksperymente. Moskva: Nauka.

5. Vezhbitskaya, Anna. 1996. Oboznacheniya tsveta unyversaliy zritelnogo vospriyatiya. Moskva: Rus. Slovari.

6. Gete, Iogann. 1996. K ucheniyu o tsvete. Moskva.

7. Gete, Iogann. 1976. Ocherki ucheniya o tsvete. Moskva: Nauka.

8. Dvoretskiy, Iosyf. 1976. Latinsko-russkiy slovar. Moskva: Russkiy yazyk.

9. Horatius Flaccus, Quintus and Ovidius Naso, Publius, and Vergilius Maro, Publius. URL: http://www/perseus.tufts.edu/

10. Malinauskene, Nadezhda. 1987. Nekotoryye osobennosti sistemy tsvetooboznacheniy v yazyke Homera. Moskva.

11. Malinovska, Oksana. 2007. "Synonimiya starohretskikh prykmetnykiv zi znachenniam "neshchasniy" u trahediyakh Eskhila, Sofokla i Evripida". PhD diss., Lviv.

12. Normanskaya, Yuliya. 2007. Tsvetooboznacheniya v sanskrite. Moskva: KomKniga.

13. Panko, Tetiana. 1974. "Slovo „zolotyy“ u poesii I. Franka”. Kiyv: Nauk. Dumka.

14. Rakhilina, Yekaterina. 2007. "O semantike prilagatelnykh tsveta”. Moskva: KomKniga.

15. Solopov, Andrey. 2007. Tsvetooboznacheniya v latinskom yazyke. Moskva: KomKniga.

16. Yanyshyn, Petr. 1996. Emotsionalnyy tsvet. Emotsionalnyi component v psikhologicheskoy strukture. Samara.

Шегедин Наталия. Семантика и стилистические функции прилагательных желтого цвета в латинском языке (на поэтических материалах августовского периода). В статье комплексно исследуются семантические и стилистические функции прилагательных желтого цвета в латинском языке на материале поэтических произведений Квинта Горация Флакка, Публия Овидия Назона и Публия Вергилия Марона. Анализируются особенности художественной реализации прилагательных желтого цвета, определяется семантическая структура основных цветообозначений. Выделяется ядро, околоядерная, периферийная и диффузная зоны. Лексико-семантическое поле прилагательных желтого цвета количественно богато и семантически разветвлено, поскольку включает лексические единицы, обозначающие всевозможные оттенки желтого. По результатам исследования определяется, что лексема flavus является семантическим центром лексикосемантического поля. Околоядерную зону составляют auratus, aureus, croceus, flavens, inauratus,luteus, где главным дифференциальным признаком выступает насыщенность цвета. Лексические единицы cereus, fulvus, gilvus, luridus, murreus, pallens, ravus, в значении которых желтый цвет теряет яркость, и акцент выражения цветового признака сдвигается в сторону темных или светлых оттенков, составляют периферию поля. В диффузной зоне выделяем flammifer, igneus, igniferus. Отмечаются две основные функции словообразования - номинативная и экспрессивностилистическая. Определяются значения прилагательных желтого цвета и их индивидуально-авторские трансформации. Цветовые определения помогают изучить путь формирования и развития многозначности слов. Семантика желтого цвета - это путь от конкретного сравнения к цветовому обобщению. Особенно выразительными функционально-стилистическими средствами оказались полисемия, метафора, эпитет. При помощи этих тропов 
создаются яркие художественные эмоционально-экспрессивные образы, привлекающие внимание читателя и в большей степени определяющие положительные или отрицательные эмоции. Семантическая полнота концепта желтого цвета отображает не только чувства и мысли поэтов, но и социальные явления в жизни античного общества. Однако на выбор лексемы влияют, прежде всего, дыхание античной эпохи и ощущение цвета поэтами.

Ключевые слова: лексико-семантическое поле, прилагательные цвета, деривация, лексема, функционально-стилистические особенности, метафора, эпитет.

Shehedyn Natalia. Semantics and Stylistic Functions of Yellow Adjectives in Latin (Based on Works of the August Period). The article is devoted to a complex analysis of the semantic and stylistic functions of yellow color adjectives in Latin based on the poetic works of Horace, Ovid and Virgil. The article analyzes the features of the artistic realization of yellow color adjectives. The semantic structure of the main color designations is analyzed. The nucleus, perinuclear, peripheral and diffuse zones are distinguished. The lexical and semantic field of yellow color adjectives is quantitatively rich and semantically embranched, as it includes lexical units that denote different shades of yellow color. Research has shown that the lexem flavus is the semantic center of the lexical and semantic field. The perinuclear zone consists of auratus, aureus, croceus, flavens, inauratus, luteus, which are allocated to this group on the basis of color saturation. Lexical units cereus, fulvus, gilvus, luridus, murreus, pallens, ravus, in the meaning of which yellow color loses brightness, so the balance of color expression is removed towards dark or light tone, will include the periphery of the field. In the diffuse zone we distinguish flammifer, igneus,igniferus. Two main functions of word formation nominative and expressive and stylistic are indicated. The meaning of yellow color adjectives and their individual authorial transformations are revealed. Color definitions help to retrace how the ambiguity of words was formed and developed. The semantics of yellow color help to trace the movement from a specific comparison to a color generalization. Polysemy, metaphor, and epithet proved to be especially expressive functional and stylistic means. Bright artistic emotional and expressive images are created with the help of these trails which attract the reader's attention. The semantic content of the concept of yellow reflects not only the feelings and thoughts of poets, but also social phenomena in the life of ancient society. However, the choice of the word is primarily in fluenced by the breath of antiquity and the sense of color by the authors.

Key words: lexical and semantic field, adjectives of color, derivation, lexical item, functional and stylistic features, metaphor, epithet. 